\title{
PENILAIAN KINERJA MUTU PENDIDIKAN AGAMA ISLAM
}

\author{
Ferdinan $^{1}$ \\ Pendidikan Agama Islam Fakultas Agama Islam| Unismuh Makassar
}

\begin{abstract}
ABSTRAK
Penilaian kinerja guru (PKG) dapat diartikan sebagai suatu upaya untuk memperoleh gambaran tentang pengetahuan, keterampilan, nilai dan sikap guru dalam melaksanakan tugas dan fungsinya, yang ditunjukkan dalam penampilan, perbuatan, dan prestasi kerjanya. Pendekatan penilaian diantaranya penilaian berfokus pegawai, penilaian berdasar perilaku, penilaian berdasar hasil yang dicapai, penilaian global. Hasil penilaian kinerja dapat digunakan oleh guru, kepala sekolah, dan pengawas untuk melakukan refleksi terkait dengan tugas dan fungsinya dalam rangka memberikan layanan kepada masyarakat.Tujuan penialaian kinerja kepala sekolah yaitu memperoleh data tentang pelaksanaan tugas pokok, fungsi dan tanggung jawab kepala sekolah dalam melaksanakan fungsifungsi manajerial dan supervisi/pengawasan pada sekolah yang dipimpinnya. Aspek yang dinilai dalam penilaian kinerja kepala sekolah mencakup tiga dimensi yakni komitmen terhadap tugas, pelaksanaan tugas, dan hasil kerja. Instrumen yang digunakan dalam penilaian kinerja adalah skala penilaian (rating scale).
\end{abstract}

\section{Kata Kunci: Kinerja, Pendidikan Agama Islam}

\section{ABSTRACT}

Teachers evaluation (PKG) can be interpreted as an attempt to gain an overview of the knowledge, skills, values and attitudes of teachers in carrying out its duties and functions, shown in appearance, actions, and work performance. Valuation approaches including employee-focused assessment, behavior-based assessment, an assessment based on the results achieved, the global assessment. Performance evaluation results can be used by teachers, principals, and supervisors for reflection related to the duties and functions in order to provide services to society. Objective evaluation performance of the principal is to obtain data on the implementation of the basic tasks, functions and responsibilities of principals in carrying out the functions managerial and supervisory / oversight at the school. Aspect considered in the assessment of the performance of the principal includes three dimensions, namely commitment to the task, task execution, and results. Instrument used in the performance evaluation is the assessment scale (rating scale).

Keyword: Work Performance, Islamic Education 


\section{PENDAHULUAN}

Sampai saat ini profesi guru masih sangat diminati oleh masyarakat, apalagi setelah adanya kebijakan pemerintah tentang sertifikasi yang memberikan tunjangan jabatan sebesar satu kali gaji pokok dan tunjangantunjangan lain yang cukup menjajikan, disisi lain pemerintah juga menuntut guru untuk profesional dalam bekerja. Menurut Mulyasa (2013), sebaiknya peningkatan mutu pendidikan ditunjang oleh guru profesional yang bermutu, yang dapat memerankan tugas dan fungsinya dengan baik dalam rangka mempersiapkan sumber daya manusia yang berkualitas melalui proses pembelajaran yang berkualitas pula.

Pengukuran kinerja suatu lembaga pendidikan merupakan hal yang sangat penting. Untuk melakukan evaluasi dan merencanakan pendidikan masa depan diperlukan pengukuran kinerja secara tepat, khususnya terhadap kinerja guru sebagai pelaksana bahkan ujung tombak pendidikan. Dalam hal ini, berbagai informasi diperlukan untuk menjamin bahwa layanan pendidikan dan pembelajaran telah dilakukan secara efektif, efisien, dan akuntabel. Dengan demikian, peningkatan mutu pendidikan harus selalu diukur kinerjanya melalui berbagai informasi, pengendalian tugas, laporan pendanaan, dan yang paling penting adalah laporan kinerja guru karena guru memiliki peran yang sangat strategis dalam menentukan mutu pendidikan, yang memerlukan syaratsyarat kepribadian dan kemampuan profesional yang standar dan dapat dipertanggungjawabkan.
Dengan kata lain, penilaian kinerja merupakan tanggung jawab (akuntabilitas) dari institusi dan individu pekerja terhadap stakholders-nya. Pekerja (dalam hal ini guru dan kepala sekolah) tidak hanya mempunyai tanggung jawab langsung kepada atasannya akan tetapi juga kepada orang tua siswa dan masyarakat pada umumnya. Kinerja mereka, baik maupun buruk, harus dipertanggungjawabkan kepada masyarakat. Apalagi bila diingat yang memperkerjakan guru dan kepala sekolah, mereka berkewajiban mengadakan sistem penilaian kinerja yang obyektif dan dapat dipertanggungjawabkan kepada masyarakat. Penilaian kinerja baik kinerja guru, kepala sekolah, dan staf (tenaga administrasi sekolah) merupakan salah satu kompetensi yang harus dikuasai pengawas sekolah/madrasah.

Adapun inti yang berkaitan dengan penilaian kinerja untuk profesi guru dan kepala sekolah, yaitu

1. Bagaimana Kinerja Pendidik dan Tenaga kependidikan?

2. Bagaimana Keberhasilan PAI?

\section{HASIL DAN PEMBAHASAN}

\section{A. Pengertian Penilaian Kinerja}

Anas Sudiono mengemukakan bahwa secara harfiah kata penilaian berasal dari bahasa Inggris "evaluation", akar katanya value yang artinya nilai. Jadi istilah penilaian menunjuk pada suatu tindakan atau suatu proses untuk menentukan nilai dari sesuatu. Menurut A. Fajar, penilaian dapat diartikan sebagai usaha untuk memperoleh berbagai informasi secara berkala, berkesinambungan, dan menyeluruh 
tentang proses yang dilakukan oleh seseorang. Berdasarkan pendapat tersebut, penilaian merupakan suatu proses atau kegiatan yang sistematis, berkelanjutan dan menyeluruh dalam rangka pengendalian, penjaminan dan penetapan kualitas berbagai komponen berdasarkan pertimbangan dan kriteria tertentu sebagai bentuk pertanggungjawaban seseorang dalam melaksanakan pekerjaannya.

Istilah kinerja atau prestasi kerja berasal dari kata job performance yaitu prestasi kerja yang dicapai seseorang dalam melaksanakan tugas pokok, fungsi dan tanggung jawab yang diberikan kepadanya. Kinerja diartikan juga sebagai tingkat atau derajat pelaksanaan tugas seseorang atas dasar kompetensi yang dimilikinya. Istilah kinerja tidak dapat dipisahkan dengan bekerja karena kinerja merupakan hasil dari proses bekerja. Dalam konteks tersebut maka kinerja adalah hasil kerja dalam mencapai suatu tujuan atau persyaratan pekerjaan yang telah ditetapkan. Kinerja dapat dimaknai sebagai ekspresi potensi seseorang berupa perilaku atau cara seseorang dalam melaksanakan tugas, sehingga menghasilkan suatu produk (hasil kerja) yang merupakan wujud dari semua tugas serta tanggung jawab pekerjaan yang diberikan kepadanya. (Ditjen PMPTK, 4: 2008)

\section{B. Penilaian Kinerja Pendidik}

\section{Pengertian Penilaian Kinerja Pendidik \\ Penilaian kinerja guru (PKG) dapat diartikan sebagai suatu upaya untuk memperoleh gambaran tentang pengetahuan, keterampilan, nilai dan}

sikap guru dalam melaksanakan tugas dan fungsinya, yang ditunjukkan dalam penampilan, perbuatan, dan prestasi kerjanya. Peraturan Menteri Pendayagunaan Aparatur Negara dan Reformasi Birokrasi Nomor 16 Tahun 2009 tentang Jabatan Fungsional Guru dan Angka Kreditnya, menegaskan bahwa penilaian kinerja guru adalah penilaian dari tiap butir kegiatan tugas utama guru dalam rangka pembinaan karier, kepangkatan, dan jabatannya. (Pedoman Pelaksanaan Penilaian Kinerja Guru, 5: 2012).

\section{Tujuan dan Manfaat Penilaian Kinerja Pendidik}

Pada Peraturan Menteri Negara Pendayagunaan Aparatur Negara dan Reformasi Birokrasi No. 16 Tahun 2009 mengatakan bahwa penilaian kinerja guru adalah penilaian yang dilakukan terhadap setiap butir kegiatan tugas utama guru dalam rangka pembinaan karir, kepangkatan, dan jabatannya. Evaluasi kinerja guru/tenaga pendidik merupakan sebuah sistem pengelolaan kinerja berbasis guru yang di buat untuk menilai/mengevaluasi tingkat kinerja guru secara individu dalam rangka mencapai kinerja sekolah secara maksimal yang berdampak pada peningkatan prestasi peserta didik. Pada umumnya tujuan pelaksanaanya evaluasi kinerja guru/tenaga pendidik ialah sebagai berikut:

a. Menentukan tingkat kompetensi seorang guru.

b. Meningkatkan efisiensi dan efektivitas kinerja guru dan sekolah.

c. Menyajikan suatu landasan untuk pengambilan keputusan dalam 
mekanisme penetapan efektif atau kurang efektifnya kinerja guru.

d. Menyediakan landasan untuk program pengembangan keprofesian berkelanjutan bagi guru.

e. Menjamin bahwa guru melaksanakan tugas dan tanggungjawabnya serta mempertahankan sikap-sikap yang positif dalam mendukung pembelajaran peserta didik untuk mencapai prestasinya.

f. sMenyediakan dasar dalam sistem peningkatan promosi dan karir guru serta bentuk penghargaan lainnya. (Pedoman PPKG,5: 2012)

Hasil penilaian kinerja juga merupakan dasar untuk melakukan perbaikan, pembinaan dan pengembangan, serta memberikan nilai prestasi kerja dan perolehan angka kredit guru dalam rangka pengembangan kariernya sesuai dengan peraturan yang berlaku. Jika semua ini dapat dilakukan dengan baik dan obyektif, pendidikan yang berkualitas dan berdaya saing dapat segera diwujudkan sehingga kita dapat membangun bangsa yang bermartabat. Hal ini dimungkinkan karena guru memiliki kinerja dan dedikasi tinggi akan dapat merencanakan, melaksanakan, dan menilai pembelajaran secar efektif, efisien dan akuntabel. (E. Mulyasa, 90: 2013)

Sebagian kalangan ada yang menganggap PKG ini merupakan sebuah bentuk sangsi terhadap kemampuan guru, terutama yang sudah memiliki sertifikat profesi. Padahal, anggapan tersebut tidaklah benar. PKG dilakukan untuk meningkatkan kemampuan penguasaan kompetensi guru dan mengembangkan kinerja keprofesiannya. Selain itu, hasil dari PKG ini pun diperlukan untuk kenaikan pangkat dan golongan guru yang bersangkutan.

\section{Syarat-Syarat Sistem Evaluasi Kinerja Tenaga Pendidik}

Dalam pelaksanaan evaluasi kinerja tenaga pendidik dibutuhkan adanya rambu-rambu/konsep evaluasi. Konsep evaluasi disini mencakup syarat sistem evaluasi, prinsip pelaksanaan, aspek yang dinilai dalam evaluasi dan perangkat pelaksanaan evaluasi. Syaratsyarat sistem evaluasi kinerja tenaga pendidik diperlukan untuk memperoleh hasil evaluasi yang benar dan tepat. Syarat-syarat tersebut antara lain:

a. Valid

Aspek yang dinilai benar-benar mengukur komponen-komponen tugas tenaga pendidik dalam melaksanakan pembelajaran, pembimbingan, dan/atau tugas lain yang relevan dengan fungsi sekolah.

b. Reliable

Mempunyai tingkat kepercayaan tinggi bila proses yang dilakukan memberikan hasil yang sama untuk seorang tenaga pendidik yang devaluasi kinerjanya oleh siapapun dan kapanpun.

c. Praktis

Dapat dilakukan oleh siapapun dengan relatif mudah, dengan tingkat validitas dan reliabilitas yang sama dalam semua kondisi tanpa memerlukan persyaratan tambahan. (Pedoman PPKG, 5: 2012) 


\section{Prinsip-Prinsip Pelaksanaan}

Prinsip-prinsip pelaksanaan evaluasi kinerja tenaga pendidik digunakan agar hasil pelaksanaan dan evaluasi kinerja tenaga pendidik dapat dipertanggungjawabkan. Adapun prinsip-prinsipnya diantaranya:

a. Berdasarkan ketentuan.

Evaluasi kinerja tenaga pendidik harus dilaksanakan sesuai dengan prosedur dan mengacu pada peraturan yang berlaku.

b. Berdasarkan kinerja.

Aspek yang dinilai dalam evaluasi kinerja tenaga pendidik adalah kinerja yang dapat diamati dan dipantau sesuai dengan tugas guru/tenaga pendidik sehari-hari dalam melaksanakan kegiatan pembelajaran, pembimbingan, dan/ atau tugas tambahan yang relevan dengan fungsi sekolah/madrasah.

c. Berlandaskan dokumen PK Guru.

Penilai, guru/tenaga pendidik yang dinilai, dan unsur lain yang terlibat dalam proses evaluasi kinerja tenaga pendidik harus memahami semua dokumen yang terkait dengan sistem evaluasi kinerja tenaga pendidik, terutama yang berkaitan dengan pernyataan kompetensi dan indikator kinerjanya secara utuh, sehingga penilai, guru/tenaga pendidik dan unsur lain yang terlibat dalam proses evaluasi mengetahui dan memahami tentang aspek yang dinilai serta dasar dan kriteria yang digunakan dalam evaluasi.

\section{Aspek Penilaian dalam PKG}

Berdasarkan Peraturan Menteri

Pendidikan Nasional Nomor 16 Tahun 2007 tentang Standar Kualifikasi
Akademik dan Kompetensi Guru, dijelaskan bahwa standar kompetensi guru dikembangkan secara utuh ke dalam 4 (empat) kompetensi utama, yaitu kompetensi pedagogik,

kepribadian, sosial, dan professional. (Jejen Musfah, 134: 2011)

Penilaian kinerja guru kelas/mata pelajaran dilakukan dengan mengacu kepada dimensi tugas utama guru yang meliputi kegiatan merencanakan dan melaksanakan pembelajaran, mengevaluasi dan menilai termasuk di dalamnya menganalisis hasil penilaian dan melaksanakan tindak lanjut hasil penilaian. Dimensi tugas utama ini kemudian diturunkan menjadi indikator kinerja yang dapat terukur sebagai bentuk unjuk kerja guru dalam melaksanakan tugas utamanya tersebut akibat dari kompetensi yang dimiliki guru. (E. Mulyasa, 95: 2013).

\section{Penilaian Kinerja Tenaga Kependidik}

Tenaga kependidikan adalah tenaga/pegawai yang bekerja pada satuan pendidikan selain tenaga pendidik. Tenaga kependidikan bertugas melaksanakan administrasi, pengelolaan, pengembangan, pengawasan, dan pelayanan teknis untuk menunjang proses pendidikan pada satuan pendidikan.

Penilaian kinerja menurut Werther dan Davis (1996:342) mempunyai beberapa tujuan dan manfaat bagi organisasi dan pegawai yang dinilai, yaitu:

a. Performance Improvement. Memungkinkan pegawai dan manajer untuk mengambil tindakan 
yang berhubungan dengan peningkatan kinerja.

b. Compensation Membantu para

Adjustment. pengambil keputusan untuk menentukan siapa saja yang berhak menerima kenaikan gaji atau sebaliknya.

c. Placement Decision. Menentukan promosi, transfer, dan demotion.

d. Training and Development Needs. Mengevaluasi kebutuhan pelatihan dan pengembangan bagi pegawai agar kinerja mereka lebih optimal.

e. Carrer Planning and Development. Memandu untuk menentukan jenis karir dan potensi karir yang dapat dicapai.

f. Staffing Process Deficiencies. Mempengaruhi prosedur perekrutan pegawai.

g. Informational Inaccuracies and Job Design Errors. Membantu menjelaskan apa saja kesalahan yang telah terjadi dalam manajemen sumber daya manusia terutama di bidang informasi job analysis, job design, dan sistem informasi manajemen sumber daya manusia.

h. Equal Employment Opportunity. Menunjukkan bahwa placement decision tidak diskriminatif.

\section{Keberhasilan Belajar Pendidikan Agama Islam}

Secara umum, keberhasilan belajar dapat diartikan sebagai suatu hasil yang dicapai setelah melakukan proses belajar. Jika diartikan menurut kosakatanya, yaitu keberhasilan dan belajar, maka dapat difahami suatu pengertian keberhasilan belajar ialah suatu hasil yang dicapai setelah melakukan aktifitas yang membawa pada perubahan individu atau suatu hasil yang dicapai setelah melakukan aktifitas belajar.

Keberhasilan belajar yang dimaksud dalam Pendidikan Agama Islam adalah suatu hasil yang dicapai setelah melakukan proses pembelajaran Pendidikan Agama Islam. Ruang lingkup Pendidikan Agama Islam di sekolah adalah meliputi lima aspek, yaitu al qur'an, aqidah, fiqih, akhlak, dan tarikh. Aspek yang diajarkan di sekolah umum (SMA) dan di sekolah agama (Aliyah) memang pada dasarnya sama, namun terdapat perbedaan dalam hal pemisahan pengajaran PAI di masingmasing aspek.

Pendidikan Agama Islam meliputi ketiga aspek, yaitu akpek kognitif, afektif, dan psikomotorik.

\section{a. Aspek Kognitif}

Keberhasilan belajar yang diharapkan pada aspek kognitif adalah keberhasilan pada penguasaan pengetahuan. Hal ini meliputi penguasaan pengetahuan yang menekankan pada:

1) Mengenal dan mengingat kembali materi yang telah diajarkan.

2) Pemahaman (comprehension), memahami hubungan yang sederhana diantara fakta-fakta atau konsep.

3) Penerapan (application), kemampuan menggunakan konsepkonsep abstrak pada objek-objek khusus dan konkret.

4) Analisis, yaitu menganalisa suatu hubungan atau situasi yang kompleks atas konsep-konsep dasar. 
5) Sintesis, yaitu kemampuan untuk menggeneralisasi pengetahuan yang didapat.

6) Evaluasi, yaitu kemampuan dalam menilai atau menyelesaikan problem baik yang bersifat kuantitatif maupun kualitatif.

\section{b. Aspek Afektif}

Aspek afektif mencakup lima aspek yaitu memperhatikan, merespon, menilai, organisasi, dan mempribadian nilai. Aspek afektif ini berhubungan dengan sikap mental, perasaan dan kesadaran siswa.

Hasil belajar dalam aspek ini diperoleh melalui proses internalisasi, yaitu suatu proses ke arah pertumbuhan batiniah dan rohaniah siswa. Pertumbuhan ini terjadi ketika siswa menyadari sesuatu nilai yang terkandung dalam pengajaran agama dan kemudian nilai-nilai itu dijadikan suatu sistem nilai diri, sehingga menuntun segenap pernyataan sikap, tingkah laku dan perbuatan moralnya dalam menjalani kehidupan ini.

\section{c. Aspek Psikomotorik}

Psikomotorik merupakan aspek yang bersangkutan dengan keterampilan yang lebih bersifat fa'aliah dan konkret. Walaupun demikian hal itu pun tidak terlepas dari kegiatan belajar yang bersifat mental (pengetahuan dan sikap). Hasil belajar aspek ini merupakan tingkah laku nyata dan dapat diamati.

Aspek psikomotorik terbagi atas tujuh aspek, yaitu:

- Persepsi, yaitu kemampuan menggunakan indra untuk memperoleh bimbingan yang bersifat kegiatan motorik.

- Kesiapan, yang meliputi kesiapan mental, kesiapan fisik, maupun kemauan untuk bertindak.

- Respon terbimbing, respon ini meliputi menirukan sesuai dengan bimbingan.

- Keterampilan mekanisme, merupakan pekerjaan yang menunjukkan bahwa respon yang dipelajari telah menjadi kebiasaan.

- Respon kompleks, keterampilan nyata gerakan motorik yang terampil.

- Adaptasi, kemampuan beradaptasi sesuai dengan situasi yang dihadapi.

- Organisasi, keterampilan polapola gerakan yang baru untuk menyesuaikan dengan situasi khusus atau bermasalah.

\section{Teknik Pengukuran}

Pengukuran adalah penentuanbesaran, dimensi, atau kapasitas, biasanya terhadap suatu standar atau satuan pengukuran. Pengukuran tidak hanya terbatas pada kuntlitas fisik, tetapi juga dapat diperluas untuk mengukur hampir semua benda yang bisa dibayangkan, seperti tingkat ketidakpastianatau kepercayaan konsumen. Pengukuran adalah proses pemberian angka-angka atau label kepada unit analisis untuk merepresentasikan atribut-atribut konsep. Proses ini seharusnya cukup dimengerti orang walau misalnya definisinya tidak dimengerti. Hal ini karena antara lain kita sering kali melakukan pengukuran. 
Secara umum alat penilaian dapat dikelompokan kedalam dua kelompok , alat penilaian bentuk tes dan alat penilaian bukan tes.

\section{a. Bentuk Tes}

Dari segi pelaksanaannya, tes dibagi kedalam tiga kategori; tes tulisan, tes lisan dan tes tindakan. Dari segi bentuk soal dapat diklasifikasikan ke dalam lima bentuk soal, yaitu (a) soal pilihan ganda, (b) soal benar salah, (c) soal menjodohkan, (d) uraian /jawaban singkat, dan (e) soal bentuk uraian bebas ( free essay). Dilihat dari segi cara atau pola jawaban yang diberikan, soal dapat dibedakan ada soal yang telah disediakan jawabannya, peserta tes tinggal memilih jawaban tersebut (pilihan ganda, benar salah, menjodohkan) dan ada soal yang tidak disediakan jawabannya (uraian). Kemudian dilihat dari segi cara pemberian skornya, dibedakan ke dalam soal yang bersifat objektif dan soal yang bersifat subjektif.

\section{b. Bentuk Non Tes}

\section{1) Wawancara dan Quistioner}

Sebagai alat penilaian, wawancara dan quistioner sangat efektif untuk menilai hasil belajar siswa yang berkaitan dengan pendapat, keyakikan, aspirasi, harapan, prestasi, keinginan dan lain-lain. Sebagai alat penilaian, wawancara memiliki kelebihan yaitu dapat berkomunikasi langsung dengan siswa, sehingga siswa dapat mengungkapkan jawaban dengan lebih bebas dan mendalam. Disamping itu, melalui wawancara dapat dibina hubungan yang lebih baik. Ada dua macam wawancara, pertama wawancara yang berstruktur dan yang kedua wawancara tidak berstruktur/bebas.

\section{2) Skala}

Skala adalah alat untuk mengukur nilai, sikap, minat atau perhatian, yang disusun dalam bentuk pernyataan untuk dinilai oleh responden yang hasilnya dalam bentuk rentangan nilai sesuai dengan kriteria yang digunakan. Ada dua jenis sekala yang sering digunakan untuk menilai proses dan hasil belajar siswa, yaitu sekala sikap dan sekala penilaian.

\section{3) Observasi}

Observasi sebagai alat penilaian banyak digunakan untuk mengukur tingkah laku individu atau terjadinya suatu proses kegiatan yang dapat diamati, baik dalam situasi yang sebenarnya maupun dalam situsi buatan. Observasi dapat mengukur atau menilai hasil dan proses belajar seperti:tingkah laku siswa pada waktu belajar, berdiskusi, mengerjakan tugas dan lainlain.

Ada tiga jenis observasi yaitu observasi langsung, observasi dengan menggunakan alat (tidak langsung) dan observasi partisipasi. Ketiga jenis observasi itu digunakan sesuai dengan tujuan dan kebutuhan dari kegiatan observasi tersebut.

\section{4) Studi kasus}

Studi kasus pada dasarnya mempelajari individu secara intensif yang dipandang memiliki kasus tertentu. Misalnya mempelajari anak yang sangat bandel/nakal, sangat rajin, sangat piter, atau sangat lamban dalam belajar. Kasus-kasus tersebut dipelajari secara 
mendalam, yaitu mengungkap segala variabel yang diduga menjadi penyebab timbulnya prilaku atau keadaan khusus tadi dalam kurun waktu tertentu. Tekanan utama dalam studi kasus adalah mencari tahu mengapa individu melakukan sesuatu dan apa pengaruhnya terhadap lingkungan.

\section{5) Sosiometri}

Banyak ditemukan di lingkungan sekolah siswa yang kurang mampu menyesuaikan diri dengan kondisi lingkungannya. Ia nampak murung, mengasingkan diri, mudah tersinggung, atau bahkan oper acting. Hal ini bisa dilihat ketika siswa sedang bermain atau sedang mengerjakan tugas-tugas kelompok. Gejala-gejala tersebut menunjukan adanya kekurang mampuan siswa dalam menyesuaikan diri dengan lingkungannya.

Sosio metri dapat dilakukan dengan cara menyuruh siswa di kelas untuk memmilih satu atau dua teman yang paling disukainya. Usahakan tidak terjadi kompromi untuk saling memilih diantara siswa. Atau dapat pula siswa disuruh memilih siswa yang kuarang disukainya. Dengan cara di atas, dapat diketahui siswa-siswa mana yang menghadapi kesulitan dalam penyesuaian diri dengan lingkungannya, kemudian diberi bantuan.

\section{KESIMPULAN}

Dapat diambil kesimpulan tentang penilaian kinerja guru dan kepala sekolah.

1. Penilaian kinerja guru (PKG) dapat diartikan sebagai suatu upaya untuk memperoleh gambaran tentang pengetahuan, keterampilan, nilai dan sikap guru dalam melaksanakan tugas dan fungsinya, yang ditunjukkan dalam penampilan, perbuatan, dan prestasi kerjanya.

2. Pendekatan penilaian diantaranya penilaian berfokus pegawai, penilaian berdasar perilaku, penilaian berdasar hasil yang dicapai, penilaian global.

3. Hasil penialaian kinerja dapat digunakan oleh guru, kepala sekolah, dan pengawas untuk melakukan refleksi terkait dengan tugas dan fungsinya dalam rangka memberikan layanan kepada masyarakat dan meningkatkan kualitas pendidikan melalui peningkatan kinerja guru, dapat digunakan sebagai bahan evaluasi diri bagi guru sehingga mengetahui kekuatan, kelemahan, peluang dan tantangan yang dimilikinya sebagai bahan untuk mengembangkan potensi dan profil kinerjanya. Tujuan penialaian kinerja kepala sekolah yaitu memperoleh data tentang pelaksanaan tugas pokok, fungsi dan tanggung jawab kepala sekolah dalam melaksanakan fungsifungsi manajerial dan supervisi/pengawasan pada sekolah yang dipimpinnya.

\section{DAFTAR PUSTAKA}

Badan PSDMPPMP. Pedoman Pelaksanaan Penilaian Kinerja Guru. Jakarta: Kementerian Pendidikan dan Kebudayaan, 2012.

Mulyasa, E. Uji kompetensi dan Penilaian Kinerja Guru. 
Bandung: Remaja Rosdakarya, 2013.

Musfah, Jejen. Peningkatan Kompetensi Guru: Melalui Pelatihan dan Sumber Belajar Teori dan Praktik. Jakarta: Kencana, 2011.

Peraturan Menteri Pendayagunaan Aparatur Negara dan Reformasi Birokrasi Nomor 16 Tahun 2009 tentang Jabatan Fungsional Guru dan Angka Kreditnya.

Peraturan Menteri Pendidikan Nasional Nomor 16 Tahun 2007 tentang Standar Kualifikasi Akademik dan Kompetensi Guru.

Peraturan Menteri Pendidikan Nasional Nomor 27 Tahun 2008 tentang Standar Kualifikasi Akademik dan Kompetensi Konselor.

Taufiq. Model-Model Pelatihan Bagi Pengawas Sekolah. Jakarta: Departemen Agama RI, 2006. 